\title{
Potassium chloride: impacts on soil microbial activity and nitrogen mineralization
}

\author{
David Gabriel Campos Pereira ${ }^{1}$ Isadora Alves Santana ${ }^{1}$ Marcio Mahmoud Megda ${ }^{2}$ iD \\ Michele Xavier Vieira Megda ${ }^{2 *}$ iD
}

${ }^{1}$ Laboratório de Fertilidade do Solo, Departamento de Ciências Agrárias, Universidade Estadual de Montes Claros (UNIMONTES), Janaúba, MG, Brasil.

${ }^{2}$ Laboratório de Fertilidade do Solo, Departamento de Ciências Agrárias, Programa de Pós graduação em Produção Vegetal no Semiárido, Universidade Estadual de Montes Claros (UNIMONTES), Campus Janaúba, 39440-000, Janaúba, MG, Brasil. E-mail: michelemegda@unimontes.br "Corresponding author.

ABSTRACT: Potassium chloride is the most widely used potassium source worldwide, and due to its continuous use, the accumulation of its salts in the soil and in plants is becoming more common. Excess available ions can cause a series of physiological disturbances in organisms and can become a biocide in the soil. The objective of this study was to evaluate the effects of the application of KCl and banana crop residues on soil chloride content, microbial activity, and soil ammonification. The experiment utilized a completely randomized $2 \times 4$ factorial design with four replicates. Treatments were as follows: two doses of vegetal residue $\left(200\right.$ and $\left.400 \mathrm{mg} \mathrm{dm}^{-3}\right) \times$ four doses of $\mathrm{KCl}(0,167,334$, and 668

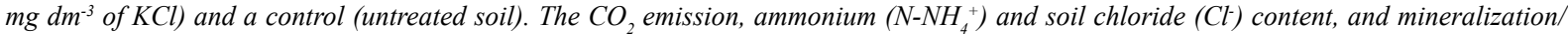
immobilization rates of the soils in each treatment were measured 4, 45, and 130 days after incubation (dai). Higher KCl dosages reduced soil microbial activity at 4 dai, regardless of the residue dosage. Microbial activity was reduced at 130 dai in all treatments when compared to the initial period. Higher dosages of banana crop residues increased the $\mathrm{Cl}^{-}$content of the soil and promoted the immobilization of $\mathrm{N}_{-} \mathrm{NH}_{4}^{+}$. We concluded that dosages of $\mathrm{KCl}$ (above $400 \mathrm{mg} \mathrm{dm}$ ), when applied to soils that already contain crop residues, reduce microbial activity and mineralization of $N$ in the soil.

Key words: respirometry, salinity, bananeira residues, ammonification.

Uso de cloreto de potássio: impacto na atividade microbiana do solo e mineralização do nitrogênio

RESUMO: O cloreto de potássio $(\mathrm{KCl})$ é a fonte de potássio mais utilizada mundialmente e, devido ao uso contínuo desse fertilizante, pode ocorrer acúmulo de sais no solo e nas plantas. O excesso de ions desencadeia uma série de distúrbios fisiológicos, tornando-se um potencial biocida no solo. Objetivou-se avaliar o efeito da aplicação de doses de $\mathrm{KCl}$ e de resíduos culturais da bananeira no teor de cloreto do solo, na atividade microbiana e na amonificação. O delineamento experimental foi inteiramente casualizado com quatro repetições. Os tratamentos foram arranjados em um fatorial $2 \times$ 4: 2 doses de resíduo vegetal (200 e $\left.400 \mathrm{mg} \mathrm{dm}^{-3}\right) \times 4$ doses de $\mathrm{KCl}(0,167,334$ e $668 \mathrm{mg} \mathrm{dm}$ (-3), além de um controle (sem aplicação de $\mathrm{KCl}$ e resíduo). Foram quantificados o $\mathrm{CO}_{2}$, o teor de amônio $\left(\mathrm{N}_{-} \mathrm{NH}_{4}^{+}\right)$e de cloreto (Cl) do solo e as taxas de mineralização/imobilização, aos 4, 45 e 130 dias após a incubação (dai). O aumento da dose de KCl reduziu a atividade microbiana, aos 4 dai, independentemente da dose de resíduo adicionada. A atividade microbiana diminuiu, aos 130 dai: em todos os tratamentos, quando comparados ao periodo inicial. O acréscimo das quantidades de resíduos culturais da bananeira aumentou o teor de Cl do solo e promoveu a imobilização do $\mathrm{N}_{-} \mathrm{NH}_{4}^{+}$. Conclui-se que doses de $\mathrm{KCl}$ maiores que $400 \mathrm{mg} \mathrm{dm} \mathrm{m}^{-3}$, associadas a presença desse residuo, reduzem a atividade microbiana e a mineralização do $N$ do solo.

Palavras-chave: respirometria, salinidade, resíduos de bananeira, amonificação.

\section{INTRODUCTION}

Banana (Musa sp.) is a socioeconomically important crop and is the most produced fruit in the world, with 107 million tons being produced worldwide per annum. Brazil is the third-largest producer of Banana, producing 7 million tons per year in an area of 461 thousand hectares (IBGE, 2018). However, crop productivity in Brazil is still considered low, particularly in the Northeast, where average annual Banana production is of $14 \mathrm{t} \mathrm{ha}^{-1}$. Among the causes of this low productivity are the scarcity of rainfall and the inadequate management of fertilization and irrigation.

Banana requires a large amount of nutrient input to produce high yields due to the large amount of vegetal mass produced. Potassium $(\mathrm{K})$ is the most required nutrient during the growth of Banana of the total macronutrients absorbed (BORGES et al., 2015). In Brazil, the amount of 
$\mathrm{K}$ recommended for adequate banana cultivation varies from 450 to $700 \mathrm{~kg} \mathrm{ha}^{-1}$ of $\mathrm{K}_{2} \mathrm{O}$ (SILVA, 2015) and, according to SILVA; BORGES \& MALBURG (1999), the of dosage $\mathrm{K}_{2} \mathrm{O}$ is commonly higher in other countries, reaching values up to $1200 \mathrm{~kg} \mathrm{ha}^{-1}$ year $^{-1}\left(2,000 \mathrm{~kg} \mathrm{ha}^{-1} \mathrm{KCl}\right)$.

Potassium chloride $(\mathrm{KCl})$ is the most widely-used K source worldwide (SILVA, 2011). However, the accumulation of ions in the soil due to fertilizer application can result in large increases in soil salinity, damaging the plants and other organisms present in the soil (VIEIRA-MEGDA et al., 2014).

The leaf litter resulting from the cultivation of bananas contains high amounts of nutrients that can be absorbed by plants and should be considered when designing fertilization programs (BORGES et al., 2015). In a study by HOFFMANN et al. (2010), K was the macronutrient which was accumulated to the greatest extent in plants. The authors concluded that $14-37 \%$ of accumulated $\mathrm{K}$ was exported via bulk transport, with the remainder being deposited in the soil.

Effects of the excessive accumulation of soluble salts on plants and microorganisms can be amplified by poor water absorption, inducing water stress. This amplification if facilitated by the toxicity of specific ions such as $\mathrm{Cl}^{-}$and by the interference of salts in physiological processes (RIETZ \& HAYNES, 2003). Excess $\mathrm{Cl}^{-}$in the protoplasm disrupts cell function, affecting the respiratory chain, $\mathrm{N}$ uptake, and protein metabolism (LARCHER, 2000; MUNNS, 2002). Increases in salt concentrations; therefore, have detrimental effects on biological processes occurring in the soil (INTRASUNGKHA et al., 1999; PANSWAD \& ANAN, 1999).

Several studies in the laboratory and in the field have shown that $\mathrm{Cl}^{-}$ions, even in low concentrations, can inhibit important processes such as ammonification and nitrification in the soil (SOURI, 2010; VIEIRA-MEGDA et al., 2014 and 2015; MARIANO et al., 2016). Thus, the evaluation of the microbial activity in saline soils is of great relevance, being helpful in the management of the potassic fertilization and improving the quality of the soil and overall productivity.

Based on the above, we hypothesized that excess $\mathrm{Cl}^{-}$, when added to the soil through potassium fertilization with $\mathrm{KCl}$ or through the decomposition of plant residues, has a biocidal effect, reducing soil microbial activity and inhibiting nitrogen cycling in the soil. The objective of this study was to evaluate soil $\mathrm{Cl}^{-}$content and its effects on microbial activity and $\mathrm{N}$ mineralization as a function of the application of $\mathrm{KCl}$ and banana crop residues.

\section{MATERIALS AND METHODS}

The experiment was conducted under aerobic incubation conditions over a period of 130 days. The experimental design was completely randomized, included four replicates, and consisted of a factorial $2 \times 4$ design with the following treatments: two doses of banana residue [200 (R1) and 400 (R2) $\left.\mathrm{mg} \mathrm{dm}{ }^{-3}\right]$ corresponding to dosages of 7.5 and $15 \mathrm{tha}^{-1}$, respectively, and four doses of $\mathrm{KCl}[0$ (0), 167 (1), 334 (2) and 668 (3) $\left.\mathrm{mg} \mathrm{dm}^{-3}\right]$, and a control plot (without the application of either vegetal residue or $\mathrm{KCl}$ ).

Vegetal residue was collected from 4-yearold banana plants ('Prata Anã' variety) which had been fertilized according to the recommendations for the culture (SOUZA et al., 1999). After collection, the residues were placed in an oven at $65{ }^{\circ} \mathrm{C}$ where they were dried to a constant mass and then passed through a Wiley mill (30 mesh). The macronutrient concentrations of the dry matter were determined and were as follows: $\mathrm{N}\left(7.3 \mathrm{~g} \mathrm{~kg}^{-1}\right), \mathrm{P}\left(0.7 \mathrm{~g} \mathrm{~kg}^{-1}\right), \mathrm{K}(3.4$ $\left.\mathrm{g} \mathrm{kg}^{-1}\right), \mathrm{S}\left(0.8 \mathrm{~g} \mathrm{~kg}^{-1}\right), \mathrm{Ca}\left(18.9 \mathrm{~g} \mathrm{~kg}^{-1}\right), \mathrm{Mg}(3.1 \mathrm{~g}$ $\left.\mathrm{kg}^{-1}\right)$; and micronutrients: $\mathrm{B}\left(19.6 \mathrm{mg} \mathrm{kg}^{-1}\right), \mathrm{Cu}(3.45$ $\mathrm{mg} \mathrm{kg}{ }^{-1}$ ), Fe (1212.5 mg kg-1), Mn (204.8 $\left.\mathrm{mg} \mathrm{kg}^{-1}\right)$,

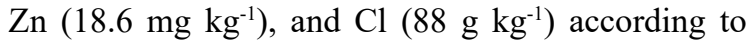
the methodologies described in MALAVOLTA et al. (1997). The $\mathrm{C} / \mathrm{N}$ ratio of the residue was 9.

The soil, classified as an Oxisol, was collected from the 0 to $0.2 \mathrm{~m}$ layer in a preserved forest (soil which had not previously been managed and had low K content) in the Cerrado area. This was then de-routed, air dried, and passed through a $2 \mathrm{~mm}$ mesh sieve. The following chemical attributes of the soil were analyzed according to the methodologies described in EMBRAPA (1997): $\mathrm{pH}$ of soil water (4.0), organic matter-colorimetric method (2.7 dag $\left.\mathrm{dm}^{-3}\right)$, phosphorus $\left(0.6 \mathrm{mg} \mathrm{dm}^{-3}\right)$ and $\mathrm{K}$ content $(35$

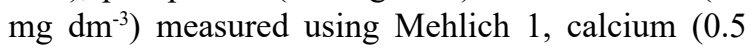
$\left.\mathrm{cmol}_{\mathrm{c}} \mathrm{dm}^{-3}\right)$, magnesium $\left(0.2 \mathrm{cmol}_{\mathrm{c}} \mathrm{dm}^{-3}\right), \mathrm{H}+\mathrm{Al}$ $\left(12 \mathrm{cmol}_{\mathrm{c}} \mathrm{dm}^{-3}\right)$, Aluminum content $\left(0.9 \mathrm{cmol}_{\mathrm{c}} \mathrm{dm}^{-3}\right)$ - extracted with $\mathrm{KCl} 1 \mathrm{~mol} \mathrm{~L}^{-1}, \mathrm{CTC}_{7}\left(12.9 \mathrm{cmol}_{\mathrm{c}} \mathrm{dm}^{-}\right.$ $\left.{ }^{3}\right), \mathrm{B}-\mathrm{CaCl}_{2}\left(0.2 \mathrm{mg} \mathrm{dm}^{-3}\right), \mathrm{Cu}^{+2}\left(0.2 \mathrm{mg} \mathrm{dm}^{-3}\right), \mathrm{Fe}^{+2}$ $\left(73.8 \mathrm{mg} \mathrm{dm}^{-3}\right), \mathrm{Mn}^{+2}\left(4.9 \mathrm{mg} \mathrm{dm}^{-3}\right)$ and $\mathrm{Zn}^{+2}$ content $\left(1.1 \mathrm{mg} \mathrm{dm}^{-3}\right)$ measured using Mehlich-1, and sand (34 dag $\left.\mathrm{kg}^{-1}\right)$, silt $\left(2 \mathrm{dag} \mathrm{kg}^{-1}\right)$, and clay $\left(64 \mathrm{dag} \mathrm{kg}^{-1}\right)$.

The dosages of $\mathrm{K}$ were based on the $\mathrm{K}$ content considered suitable for growing bananas-120 $\mathrm{mg} \mathrm{dm}^{-3}$ of K (SOUZA et al., 1999) considering the soil content $\left(35 \mathrm{mg} \mathrm{dm}^{-3}\right)$ and corresponding to dosages of $300 \mathrm{~kg} \mathrm{ha}^{-1}$ of $\mathrm{K}_{2} \mathrm{O}$. As a result, the dosages were setup to reflect dosages of $200-800 \mathrm{~kg} \mathrm{ha}^{-1}$ of $\mathrm{K}_{2} \mathrm{O}$.

Experimental units were composed of $300 \mathrm{ml}$ plastic containers containing $50 \mathrm{~g}$ of air- 
dried fine earth. To correct for the inherent soil acidity, calcium carbonate was applied to the soils with the aim of increasing the soil's saturation to $70 \%$. $8 \mathrm{~g}$ of water was also added to maintain the maximum soil water retention capacity (CMRA) at $50 \%$, according to the methods of BREMNER \& SHAW (1958). The soil was then pre incubated under aerobic conditions for 20 days to reactivate microbial biomass. Phosphate fertilizer (triple superphosphate) was applied at a dosage equivalent to $120 \mathrm{~kg} \mathrm{ha}^{-1}$ of $\mathrm{P}_{2} \mathrm{O}_{5}$. Mineral $\mathrm{N}$ was not applied considering that one of the objectives of the study was to estimate the mineralization of $\mathrm{N}$.

After the pre-incubation period, the treatments were diluted with distilled water and applied superficially to banana residues and incorporated into the soil in order to raise the soil moisture to $70 \%$ CMRA and maintain the conditions considered adequate for soil organisms. The respirometry and $\mathrm{N}_{-} \mathrm{NH}_{4}^{+}$and $\mathrm{Cl}^{-}$content of the soil was measured at 4 and 130 days after incubation (dai) and mineralization/immobilization was estimated at 4, 45, and 130 dai.

Quantification of the evolved $\mathrm{CO}_{2}$ (mineralizable C) was performed using the respirometry technique of CURL \& RODRIGUEZKABANA (1972) and STOTZKY (1965). Soil samples were conditioned in plastic containers and hermetically sealed at room temperature $\left(27{ }^{\circ} \mathrm{C} \pm\right.$ $0.6)$. Thirty milliliters of $0.5 \mathrm{M} \mathrm{NaOH}$ was added to capture the $\mathrm{CO}_{2}$ released by the respiration of heterotrophic microorganisms.
Extraction of $\mathrm{N}_{-} \mathrm{NH}_{4}^{+}$was carried out according to the methodology of CANTARELLA \& TRIVELIN (2001) with a solution of $\mathrm{KCl} 2.0 \mathrm{~mol} \mathrm{~L}^{-1}$ in the ratio of $1: 5$ (soil:solution). The $\mathrm{N}^{-\mathrm{NH}_{4}}{ }^{+}$was quantified by steam distillation. $\mathrm{Cl}^{-}$was extracted in an aqueous solution and titrated with $\mathrm{AgNO}_{3}$ in the presence of $\mathrm{K}$-chromato as an indicator (EMBRAPA, 1997). Using the difference between the $\mathrm{N}_{-} \mathrm{NH}_{4}^{+}$ content reported in each treatment and the control (soil only), it was possible to estimate the nutrient content derived from the mineralization (ammonification) or immobilization of native soil $\mathrm{N}$ at each measurement interval (4, 45 and 130 dai).

The normality of the data was verified by the Shapiro-Wilk (W) test with significance set at 5\% probability. Analyses were performed using the statistical analysis software R. Analysis of variance (ANOVA) was used to examine the data using the $\mathrm{F}$ test. The Tukey test $(\mathrm{p}<0.05)$ was used to detect significant causes of variation in relation to the residual interaction $\mathrm{x} \mathrm{KCl}$. Regression analysis was used to identify meaningful interactions caused by variation in $\mathrm{KCl}$ dosage (assuming constant residue dosage) based on results of the ANOVA and coefficient $t$ tests.

\section{RESULTS AND DISCUSSION}

The interaction $\mathrm{KCl} \times$ residue had a significant effect on soil microbial activity at day 4 and 130 (Figures 1 and 2). Increasing $\mathrm{KCl}$ dosage reduced microbial activity at day 4 , with the $\mathrm{KCl} 1$ treatment
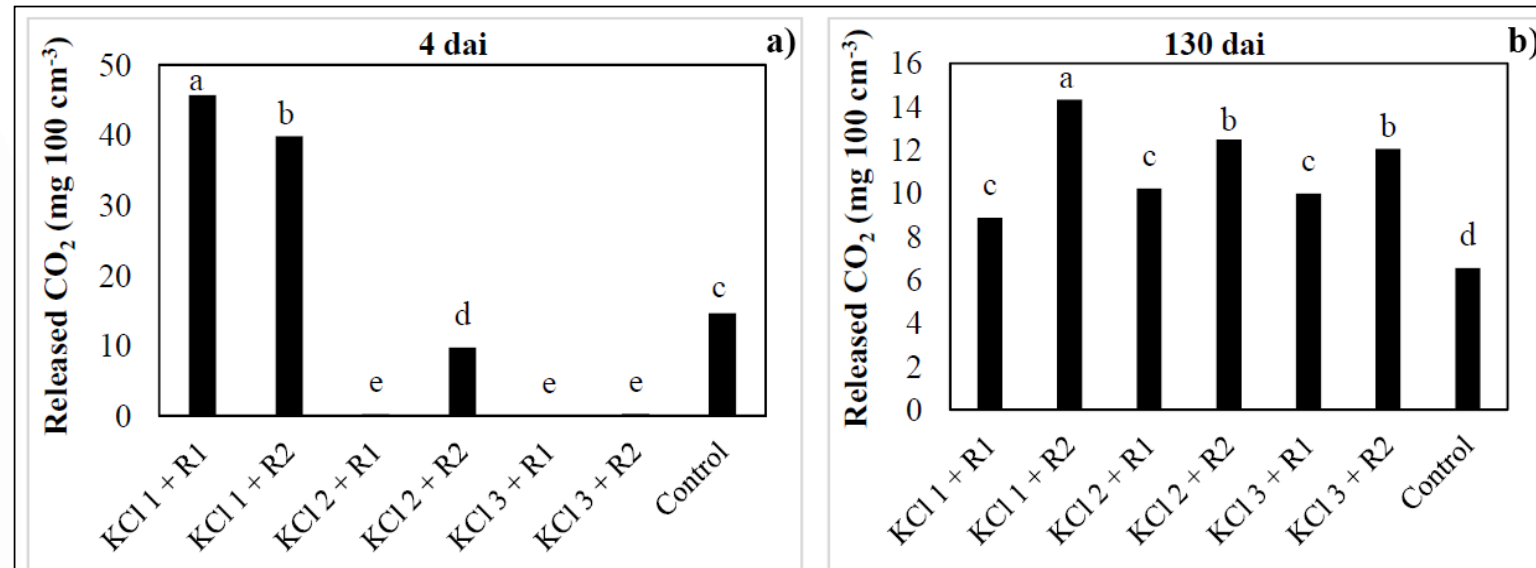

Figure 1 - Effect of potassium chloride $(\mathrm{KCl})$ associated to doses of bananeira residue on soil microbial activity at 4 (a) and 130 (b) days after incubation (dai). The $\mathrm{KCl} \mathrm{1,} \mathrm{KCl} 2$ and $\mathrm{KCl} 3: 167,334$ and $668 \mathrm{mg} \mathrm{dm}^{-3}$ of KCl, respectively. The R1 and R2: 200 and $400 \mathrm{mg} \mathrm{dm}^{-3}$ of residue, respectively. Control: without $\mathrm{KCl}$ and residue application. 
releasing the most $\mathrm{CO}_{2}(52.2 \mathrm{mg})$, regardless of the residue dosage used (Figure 1a). Microbial activity in the control was equal to or greater than in the $\mathrm{KCl} 2$ and $\mathrm{KCl} 3$ treatments at both residue dosages, highlighting the antagonistic effect of the application of high dosages of $\mathrm{KCl}$.

At day 4, we observed variable increases in emitted $\mathrm{CO}_{2}$ in the $\mathrm{KCl} 1+\mathrm{R} 1$ and $\mathrm{KCl} 1+\mathrm{R} 2$ treatments based on residue dosage (Figure 1a). This result suggested that excessive increases in the amount of labile organic $\mathrm{C}$ from banana residues ( $\mathrm{C} / \mathrm{N}$ equals 9) in the soil had no positive effect on the activity of soil microorganisms during the initial period. The significance of the $\mathrm{KCl} \times$ residue interaction is primarily due to the fact that banana residue has a high nutrient content, and that after decomposition and mineralization, nutrients are readily available in the soil solution and are absorbed by plants and microorganisms (HOFFMANN et al., 2010). By analyzing the residue, we reported that the concentration of $\mathrm{Cl}$ was very high $\left(88 \mathrm{~g} \mathrm{~kg}^{-1}\right)$, which initially caused a toxic effect in soil microorganisms.

Considering the absolute values of $\mathrm{CO}_{2}$ release at 130 dai (Figure $1 \mathrm{~b}$ ), a reduction in microbial activity was observed in all treatments (relative to values from 4 dai; Figure 1a). $\mathrm{CO}_{2}$ release was, on average, $50 \mathrm{mg} 100 \mathrm{~cm}^{-3}$ soil at 4 dai and 14 $\mathrm{mg} 100 \mathrm{~cm}^{-3}$ at 130 dai, indicating that over time the harmful effects of excess salts in the soil increased. This result also suggests the possible exhaustion of labile $\mathrm{C}$ substrata. However, at 130 dai (Figure $2 \mathrm{~b}$ ) the treatment with a residue dosage of $400 \mathrm{mg}$ $\mathrm{dm}^{-3}$ promoted higher $\mathrm{CO}_{2}$ emissions from the soil, suggesting higher microbial activity. The high amount of $\mathrm{C}$ in the soil in treatments with the highest residue dosages likely facilitated the survival of soil microbes by providing them an additional energy source (KAISER et al., 1995). In addition, greater soil microbial activity was observed in the latter period of the experiment and associated with higher $\mathrm{K}$ dosages, possibly due to the adaptive capacity of the soil microbiota.

VIEIRA-MEGDA et al. (2014) stated that the soil microbiota can become resilient to the negative effects of certain soil conditions. This is due to the ability of microorganisms to rapidly adapt to their environment, as demonstrated by the observed increase in microbial respiration at 130 dai with increasing doses of $\mathrm{KCl}$.

According to other studies, the salinity tolerance limit of organisms depends on the concentration of salt in the soil solution, exposure duration, and the stage of development of affected the plants and microorganisms, with the initial stages of exposure being the most critical (SANTANA et al., 2007; VIEIRA-MEGDA et al., 2014 and 2015). SÁNCHEZ et al. (2004) evaluated the induced inhibition of nitrification by $\mathrm{Cl}^{-}$ions, reporting low $\mathrm{NH}_{4}^{+}$and nitrite oxidation rates after the application of $70 \mathrm{~g} \mathrm{~L}^{-1}$ of $\mathrm{NaCl}$. However, the oxidative capacity of soil microorganisms later recovered, demonstrating the resilience of soil microorganisms when placed under adverse conditions.

In relation to soil $\mathrm{N}-\mathrm{NH}_{4}^{+}$content, higher residue dosages were associated with reductions in $\mathrm{N}-\mathrm{NH}_{4}^{+}$content (Figure 2), possibly due to more

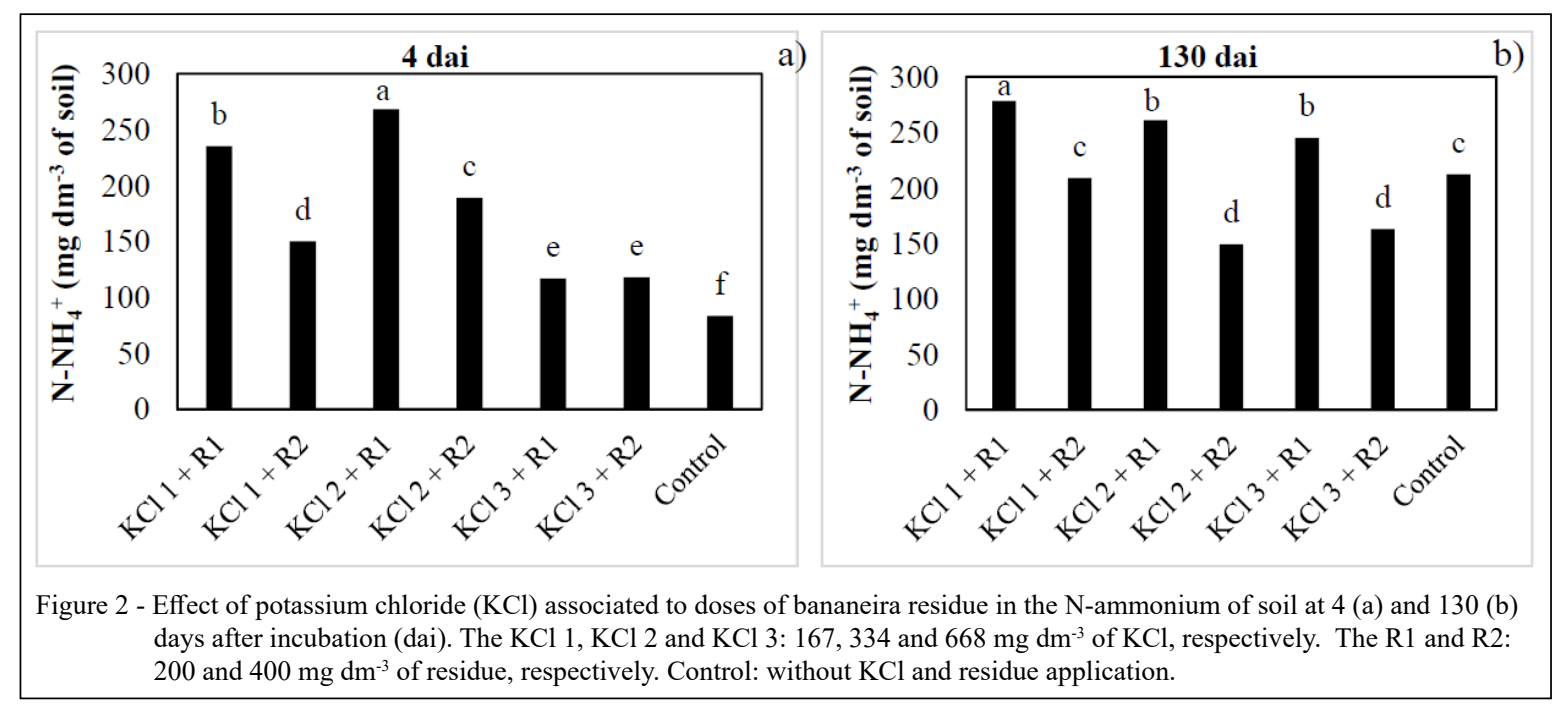

Ciência Rural, v.49, n.5, 2019. 
efficient $\mathrm{N}$ absorption caused by the higher biomass and carbon content of the soil. SOUZA et al. (2006) evaluated the effects of different soil systems and uses on the fractions of microbial activity and organic carbon present in oxisols, finding that (relative to an area used in conventional tulip cultivation) the soils of the Cerrado area contained three times more carbon of the light fraction (CFL) and; consequently, exhibited greater microbial activity. According to the authors, the high carbon content of the soils in native Cerrado is caused by the increased input of organic residues into the soil due to more abundant leaf litter and higher rhizo deposition. Heightened soil carbon content is also facilitated by the low-intensity decomposition occurring in more rural areas away from the influence of human activity.

Commonly, the exchangeable nutrient content of the soil is used as the basis upon which $\mathrm{K}$ application recommendations are made. However, K, as well as other nutrients, may already be available in the soil as a result of the mineralization of plant residues deposited on the surface (SIMONSSON et al., 2007). CATTELAN et al. (1997) concluded that microbial development was stimulated by increased organic carbon and soil water availability. According to GERALDES et al. (1995), in addition to the difference in microbial biomass occurring between different preparation systems, there is a seasonal variation of the microbial biomass, which is a direct relation between the increase in the population of the microbial biomass with the availability of nutrients from the litter and the increase of soil moisture at the beginning of the rainy season.

The average $\mathrm{N}_{-} \mathrm{NH}_{4}^{+}$content in the soil increased with time, with values of $155 \mathrm{mg} \mathrm{dm}^{-3}$ at day 4 and $210 \mathrm{mg} \mathrm{dm}^{-3}$ at day 130 (Figures 2a and $2 \mathrm{~b}$ ). In this same period, a decrease in the $\mathrm{CO}_{2}$ released because of microbial activity (Figure 1B) was observed, which may be related to the higher availability of $\mathrm{N}$, that is, with lower microbial activity in the soil, nutritional needs are reduced.

Increase in soil $\mathrm{C}$ availability through the addition of organic residues can immediately stimulate microbial activity and is known as the priming effect (AZAM \& IFZAL., 2006). In addition, the reduction in microbial growth due to several factors, such as excess salts and water scarcity, may reduce biomass and nutritional demand for nutrients (GRAHAM et al., 2002).

In relation to the interactions $\mathrm{K} x$ residue for the net content of $\mathrm{N}_{-} \mathrm{NH}_{4}^{+}$, there was an influence of the $\mathrm{KCl}$ doses, according to the model of the equations shown in figure 3 . At day 4 , the quadratic effect of the $\mathrm{N}_{-} \mathrm{NH}_{4}^{+}$content was observed as a function of the $\mathrm{KCl}$ doses associated with the addition of banana plant residues $(p \leq 0.01)$ (Figure 3a). Doses that provided the highest levels of $\mathrm{N}_{-} \mathrm{NH}_{4}^{+}$in the soil $\left(274.4\right.$ and $\left.188 \mathrm{mg} \mathrm{dm}^{-3}\right)$ were 206.3 and $225.1 \mathrm{mg} \mathrm{dm}^{-3} \mathrm{KCl}$ with a dose of 200 and $400 \mathrm{mg} \mathrm{dm}^{-3}$ of residue, respectively, with a depressant effect on the net content of $\mathrm{NH}_{4}^{+}$from that dose (Figure 3a).

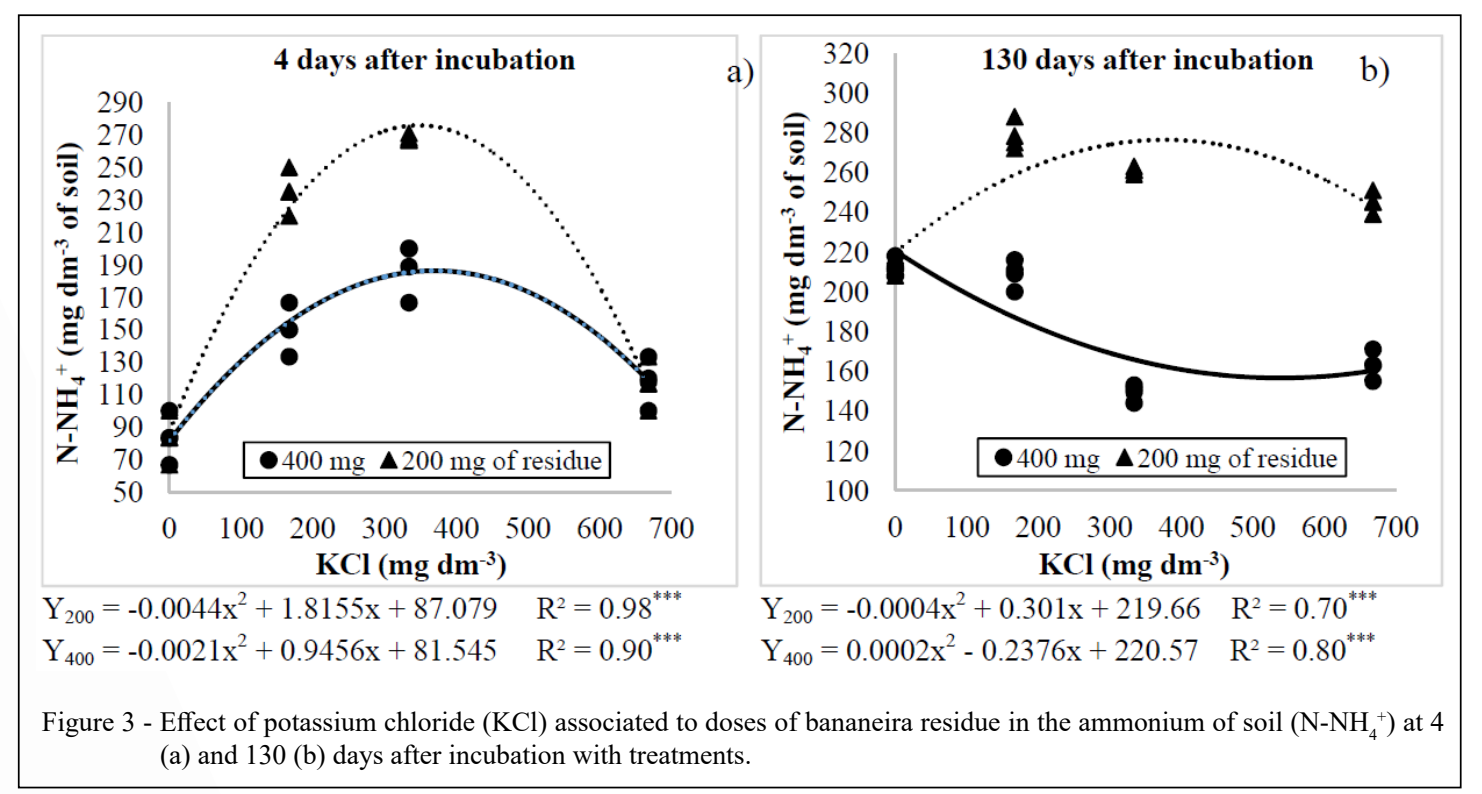

Ciência Rural, v.49, n.5, 2019. 
At day 130, the dose that provided the maximum content of $\mathrm{N}^{-\mathrm{NH}_{4}}{ }_{4}$ in the soil $(276.3 \mathrm{mg}$ $\mathrm{dm}^{-3}$ ) was $375 \mathrm{mg} \mathrm{dm}^{-3}$ of $\mathrm{KCl}$ associated with 200 $\mathrm{mg} \mathrm{dm}^{-3}$ of residue. In relation to the higher residue dose, a reduction in $\mathrm{N}-\mathrm{NH}_{4}^{+}$levels was observed with increasing $\mathrm{KCl}$ doses. These results demonstrated the deleterious effect caused by the excessive use of potassium fertilizer on the production of $\mathrm{N}^{-\mathrm{NH}_{4}^{+}}$, mainly owing to the reduction in microbial activity. It is aggravated by the fact that banana is a perennial crop with continuous addition of saline fertilizers, such as $\mathrm{KCl}$, which can lead to the accumulation of salts in the soil, mainly in semi-arid or arid regions, where banana is irrigated by drip irrigation or micro aspersion. High concentrations of $\mathrm{Cl}^{-}$in the residue remain free in the cell, being easily part of the soilplant system and when in excess, can form oxidative compounds, which degrade the cells, resulting in death of soil microorganisms (CHEN \& WONG, 2004; CHRISTENSEN et al., 1981).

The increase of the $\mathrm{KCl}$ doses promoted an increase in the available $\mathrm{Cl}^{-}$content in the soil solution for both evaluated periods (Figure 4). It is worth mentioning that the higher dose of applied residue promoted greater availability of $\mathrm{Cl}^{-}$content for absorption by the microorganisms. Saline stress can also reduce the absorption and transport of essential elements for the development and growth of plants and soil organisms, causing a nutritional imbalance that is an important component of salt stress. According to MARSCHNER (1997), $\mathrm{Cl}^{-}$is the most toxic anion, and $\mathrm{Na}^{+}$is the most damaging cation in plant metabolism.

High concentrations of salts have negative effects on several bacterial groups responsible for nitrification, directly influencing the organic matter and N cycle (INTRASUNGKHA et al., 1999). In a study carried out by PANSWAD \& ANAN (1999), the authors verified that a gradual increase of 0 to $18 \mathrm{~g} \mathrm{~L}^{-1}$ of $\mathrm{Cl}^{-}$resulted in losses of nitrifying activity of 33 to $55 \%$ and, according to these authors, the effect is due to the high reactivity of chlorinated compounds, responsible for the oxidative action of organic matter, as it diffuses easily through cell walls of microorganisms and reacts with cellular proteins, oxidizing active points essential to cellular respiration, destroying vital structures, and thus causing their death (MCGUIRE et al., 1999).

The increase in soil $\mathrm{KCl}$ had a positive effect on the microbial activity at 130 day to the doses of 422 and $429 \mathrm{mg} \mathrm{dm}^{-3}$ and with 200 and $400 \mathrm{mg}$ of residue, respectively (Figure 5a). Similar results were reported by VIEIRA-MEGDA et al. (2014), when studying the effect of $\mathrm{NH}_{4} \mathrm{Cl}$ on nitrification and $\mathrm{C}$ of microbial biomass. Other authors also reported similar results when studying the application of high levels of salts in the soil, which directly affected the biochemical processes of plants and soil biotics (PENNES \& CALLAWAY, 1992; MUNSTERS \& TERMAAT, 1986).

At day 4, treatments with higher doses of organic residues resulted in lower $\mathrm{N}-\mathrm{NH}_{4}^{+}$yields in

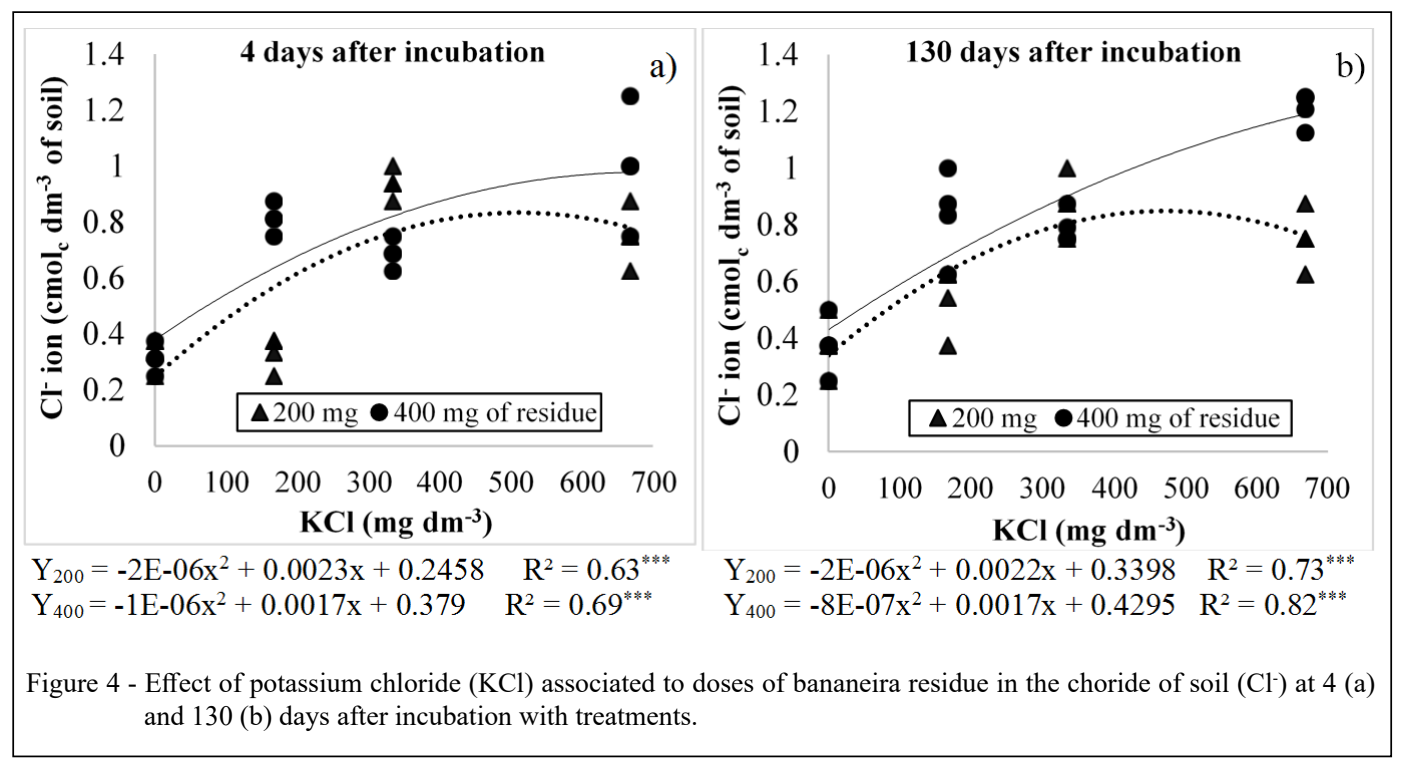

Ciência Rural, v.49, n.5, 2019. 


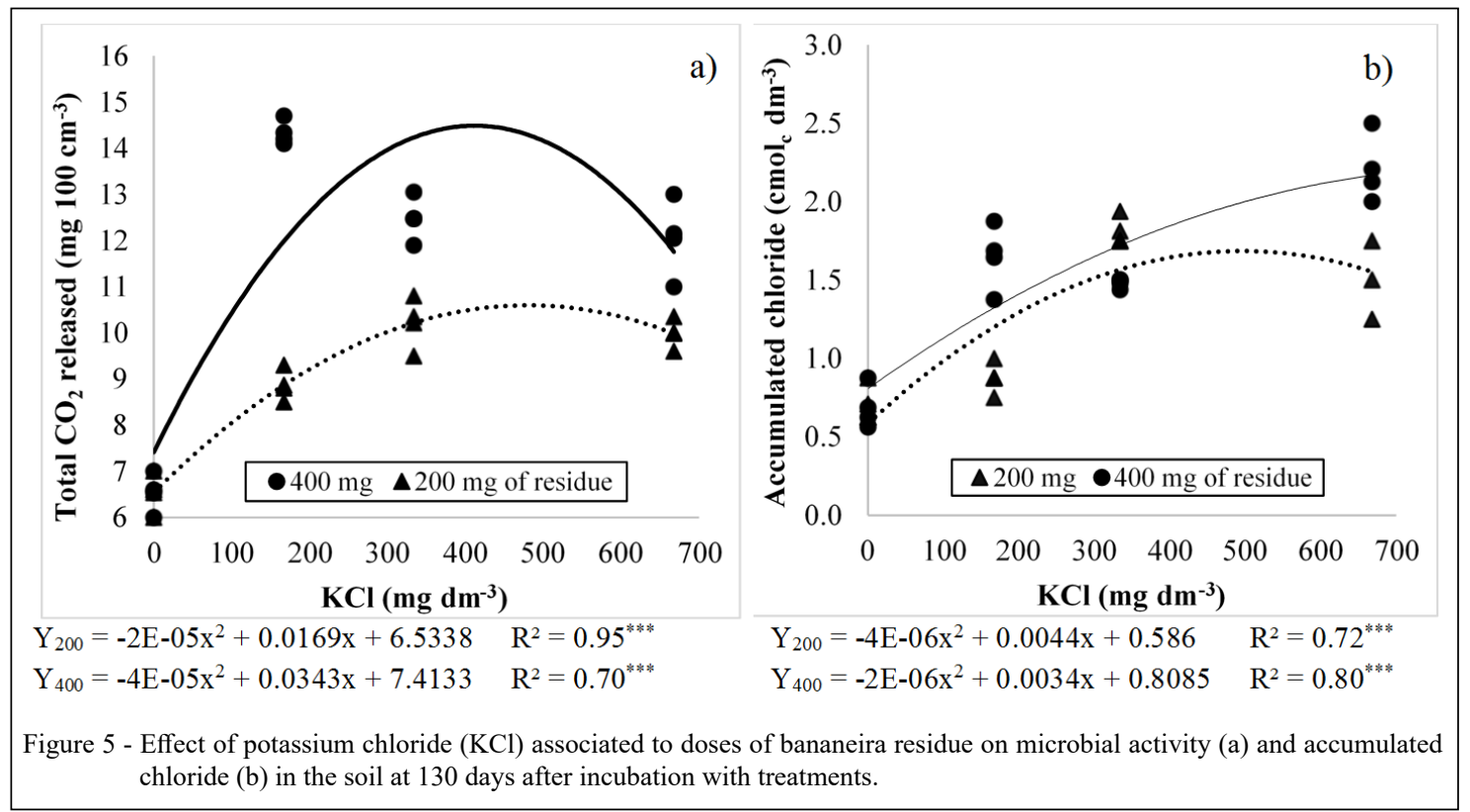

the soil, on average $50 \mathrm{mg} \mathrm{dm}^{-3}$ less when compared to treatments where $200 \mathrm{mg} \mathrm{dm}^{-3}$ of plant residue was added (Table 1). These results suggested that the higher dosages of organic residue resulted in the lower mineralization of organic $\mathrm{N}$ and the greater immobilization of available $\mathrm{N}_{-} \mathrm{NH}_{4}^{+}$in the soil. Heightened organic matter decomposition in the early stages of the experiment caused by increases in the sizes of microbial populations in the soil promoted the temporary immobilization of nutrients (DIJKSTRA et al., 2004 and 2005; JANDL et al., 2007).
In addition, we found that when large amounts of residue are applied, available $\mathrm{Cl}^{-}$ accumulation is increased in the soil solution (Figure $5 \mathrm{~b}$ ). These results are reinforced by those presented in figures $3 \mathrm{~b}$ and $5 \mathrm{a}$, which illustrate that greater soil microbial activity was observed at day 130 and was associated with the higher immobilization of $\mathrm{N}_{-} \mathrm{NH}_{4}^{+}$and lower $\mathrm{N}-\mathrm{NH}_{4}^{+}$liquid content in the solution. The highest net availability of $\mathrm{N}_{-} \mathrm{NH}_{4}^{+}$at the end of the experiment (130 dai) was observed in the treatment $\mathrm{KCl} 2+\mathrm{R} 1$, in which the average $\mathrm{N}_{-} \mathrm{NH}_{4}^{+}$ content was $300 \mathrm{mg} \mathrm{dm}^{-3}$. Conversely, in the $\mathrm{KCl}$

Table 1 - Ammonium content in the soil $\left(\mathrm{N}_{-} \mathrm{NH}_{4}{ }^{+}\right)$from mineralization (ammonification) or immobilization of soil nitrogen as function of the aplication of potassium chloride $(\mathrm{KCl})$ and bananeira residues at 4, 45 e 130 days after incubation (day).

\begin{tabular}{lcccc}
\hline Treatment & & & & Liquid production of N-NH $_{4}{ }^{+}$ \\
\hline & day 4 & day 45 & day 130 & $\left(\mathrm{mg} \mathrm{dm}^{-3}\right)$ \\
$\mathrm{KCl} 1+\mathrm{R} 1$ & 100.0 & 22.2 & 70.0 & 192.2 \\
$\mathrm{KCl} 1+\mathrm{R} 2$ & 50.0 & 133.3 & 0.0 & 183.3 \\
$\mathrm{KCl} 2+\mathrm{R} 1$ & 166.7 & 83.3 & 50.0 & 300.0 \\
$\mathrm{KCl} 2+\mathrm{R} 2$ & 100.0 & 116.7 & -56.0 & 160.7 \\
$\mathrm{KCl} 3+\mathrm{R} 1$ & 0.0 & 83.3 & 33.3 & 116.7 \\
$\mathrm{KCl} 3+\mathrm{R} 2$ & -33.3 & -16.7 & -33.3 & -83.3 \\
\hline
\end{tabular}

$\mathrm{KCl} \mathrm{1,} \mathrm{KCl} 2$ and $\mathrm{KCl}$ 3: 167, 334 and $668 \mathrm{mg} \mathrm{dm}^{-3}$ of $\mathrm{KCl}$, respectively. R1 e R2: 200 and $400 \mathrm{mg}^{-3}$ of banana residue, respectively. Negative values represent to imobilization of available inorganic nitrogen. 


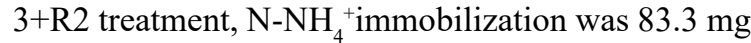
$\mathrm{dm}^{-3}$, leading to a N-NH${ }_{4}^{+}$deficit in the soil solution (Table 1).

\section{CONCLUSION}

The accumulation of cultural banana residues in association with the application of $\mathrm{KCl}$ doses greater than $400 \mathrm{mg} \mathrm{dm}^{-3}$ reduces microbial activity in the soil, and this effect only intensifies over time.

Addition of $\mathrm{KCl}$ reduces the net ammonium content of the soil when applied at doses of $206 \mathrm{mg} \mathrm{dm}^{-3}$ or higher. Reduction is also associated with increases in the accumulation of vegetal banana residues in the soil, which increases the immobilization of native inorganic $\mathrm{N}$ in the soil.

\section{ACKNOWLEDGMENTS}

To the State University of Montes Claros (UNIMONTES) for the infrastructure, FAPEMIG for the scholarship of scientific initiation granted and was financed in part by the Coordenação de Aperfeiçoamento de Pessoal de Nível Superior (CAPES), Brasil - Finance code 001.

\section{AUTHORS' CONTRIBUTIONS}

All authors contributed equally for the conception and writing of the manuscript. All authors critically revised the manuscript and approved of the final version.

\section{REFERENCES}

AZAM, F.; IFZAL, M. Microbial populations immobilizing $\mathrm{NH}_{4}^{+}-\mathrm{N}$ and $\mathrm{NO}_{3}^{-}-\mathrm{N}$ differ in their sensitivity to sodium chloride salinity in soil. Soil Biology and Biochemistry, Oxford, v.38, p.2491-2494, 2006. Available from: <https://doi.org/10.1016/j. soilbio.2006.01.028>. Accessed: Nov. 26, 2018. doi: 10.1016/j. soilbio.2006.01.028.

BORGES, A.L. et al. Nutrient accumulation in ' $d$ ' angola' plantain (terra type) under doses of nitrogen applied by irrigation water. Revista Brasileira de Fruticultura, Jaboticabal, v.37, p.488-496, 2015. Available from: <http://dx.doi.org/10.1590/0100-2945086/14>. Accessed: Apr. 02, 2019. doi: 10.1590/0100-2945-086/14.

BREMNER, J.M.; SHAW, K. Denitrification in soil: II. Methods of investigation. Journal of Agricultural Science. v.51, p.22-39, 1958. Available from: <https://oi.org/10.1017/ S0021859600032767>. Accessed: Nov. 28, 2017. doi: 10.1017/ S0021859600032767.

CANTARELla, H.; TRIVELIN, P.C.O. Determinação de nitrogênio inorgânico em solo pelo método da destilação a vapor. In: Análise química para avaliação da fertilidade de solos tropicais. Campinas: Instituto Agronômico, 2001. cap.19, p.270-276.

CATTELAN, A.J. et al. Crop rotation systems under no-till and soil microorganisms, during the soybean crop, in Londrina. Revista
Brasileira de Ciência do Solo, Campinas, v.21, p.293-301, 1997. Available from: <https://ainfo.cnptia.embrapa.br/digital/bitstream/ item/121165/1/id-191270001.pdf > . Accessed: Nov. 20, 2018.

CHEN, G.H.; WONG, M.T. Impact of increased chloride concentration on nitrifying activated sludge cultures. Journal of Environmental Engineering, Reston, v.130, p.116125, 2004. Available from: <https://www.researchgate.net/ publication/245300715>. Accessed: Nov. 28, 2017. doi: 10.1061/ (ASCE)0733-9372(2004)130:2(116).

CHRISTENSEN, N.W. et al. Chloride effects on water potentials and yield of winter wheat infected with take-all root rot. Agronomy Journal, Madison, v.73, p.1053-1058, 1981. Available from: $<$ https://dl.sciencesocieties.org/publications/aj/abstracts/73/6/ AJ0730061053>. Accessed: Nov. 19, 2017. doi: 10.2134/ agronj1981.00021962007300060035x.

CURL, E.A.; RODRIGUEZ-KABANA, R. Microbial interactions. In: WILKINSON, R.E., ed. Research methods in weed science. Atlanta, Southern Weed S. Society, 1972. p.162-194.

DIJKSTRA, F. A. et al. Nitrogen deposition and plant species interact to influence soil carbon stabilization. Ecology Letters, Wiley, v.7, p.1192-1198, 2004. Available from: <http://dx.doi.or g/10.1111/j.1461-0248.2004.00679.x>. Accessed: Mar. 19, 2018. doi: 10.1111/j.1461-0248.2004.00679.x.

DIJKSTRA, F. A. et al. Divergent effects of elevated $\mathrm{CO}_{2}, \mathrm{~N}$ fertilization, and plant diversity on soil $\mathrm{C}$ and $\mathrm{N}$ dynamics in a grassland field experiment. Plant and Soil, Springer, v.272, p.41-52, 2005. Available from: <http://dx.doi.org/10.1007/s11104-004-38486>. Accessed: Feb. 30, 2018. doi: 10.1007/s11104-004-3848-6.

EMPRESA BRASILEIRA DE PESQUISA AGROPECUÁRIA EMBRAPA. Manual de métodos de análises de solo. 2. ed. Rio de Janeiro: MAPA, 1997. 212 p.

GERALDES, A. P. A. et al. Biomassa microbiana de solo sob pastagens na Amazônia. Revista Brasileira de Ciência do Solo, Campinas, v.19, p.55-60, 1995. Available from: <http:// www.scielo.br/scielo.php? script $=$ sci_serial\&pid $=0100$ 0683\&lng=en\&nrm=iso $>$. Accessed: Nov. $22,2018$.

GRAHAM, M.H. et al. Soil organic matter content and quality: effects of fertilizer applications, burning and trash retention on a long-term sugarcane experiment in South Africa. Soil Biology and Biochemistry, v.34, p.93-102, 2002. Available from: $<$ https://doi. org/10.1016/S0038-0717(01)00160-2>. Accessed: Nov. 18, 2018. doi: 10.1016/S0038-0717(01)00160-2.

HOFFMANN, R.B; et al. Accumulation of dry matter and macronutrient in cultivars of irrigated banana tree. Revista Brasileira de Fruticultura, Jaboticabal, v.32, p.268-275, 2010. Available from: <http://dx.doi.org/10.1590/S010029452010005000026>. Accessed: Apr. 10, 2018. doi: 10.1590/ S0100-29452010005000026.

IBGE - Brazilian Institute of Geography and Statistics. Levantamento sistemático da produção agrícola. Available from: $<$ https://www.ibge.gov.br/estatisticas-novoportal/economicas/ agricultura-e-pecuaria/9201-levantamento-sistematico-daproducao-agricola.html?=\&t=resultados $>$. Accessed: Apr. 02, 2019.

INTRASUNGKHA, $\mathrm{N}$. et al. Biological nutrient removal efficiency in treatment of saline waste water. Water Science and 
Technology, v.39, p.183-190, 1999. Available from: <https://doi. org/10.1016/S0273-1223(99)00138-9>. Accessed: Apr. 15, 2018. doi: 10.1016/S0273-1223(99)00138-9.

JANDL, R. et al. How strongly can forest management influence soil carbon sequestration? Geoderma, v. 137, p.253-268, 2007. Elsevier BV. Available from: <http://dx.doi.org/10.1016/j.geoderma.2006.09.003>. Accessed: Apr. 12, 2018. doi: 10.1016/j.geoderma.2006.09.003.

KAISER, E.A. et al. Temporal changes in soil microbial biomass carbon in an arable soil. Consequences for soil sampling. Plant and Soil, v.170, p.287-295, 1995. Available from: <https:// doi.org/10.1007/BF00010481>. Accessed: Nov. 18, 2018. doi: 10.1007/BF00010481.

LARCHER, W. Ecofisiologia vegetal. São Carlos: RIMA. 2000. 531p.

MALAVOLTA, E. et al. Avaliação do estado nutricional de plantas. 2. ed. Piracicaba: Potafos, 1997. 319p.

MARSCHNER, H. Mineral nutrition higher plants. San Diego: Academic Press, 1997. 889p.

MARIANO, E. et al. Biomass and Nutrient Content by Sugarcane as Affected by Fertilizer Nitrogen Sources. Crop Science. v.56, p.1-11, 2016. Available from: <https://www.researchgate.net/ publication/299472250>. Accessed: Feb. 13, 2018. doi: 10.2135/ cropsci2015.06.0349

MCGUIRE, M.J. et al. Using chlorite ion to control nitrification. Journal of the American Water Works Association, v.91, p.52-61, 1999. Available from: $<$ https://doi.org/10.1002/j.1551-8833.1999. tb08715.x>. Accessed: May. 14, 2018. doi: 10.1002/j.15518833.1999.tb08715.x.

MUNNS, R. Comparative physiology of salt and water stress. Plant, Cell and Environment, v.25, p.239-250, 2002. Available from: $<$ https://doi.org/10.1046/j.0016-8025.2001.00808.x >. Accessed: Jun. 25, 2018. doi: 10.1046/j.0016-8025.2001.00808.x.

PANSWAD, T.; ANAN, C. Specific oxygen, ammonia and nitrate uptake rates of a biological nutrient removal process treating elevated salinity wastewater. Bioresource Technology. v.70. p.237-423. 1999. Available from: <https://www.researchgate.net/ publication/221986235>. Accessed: May, 12, 2018. doi: 10.1016/ S0960-8524(99)00041-3.

PENNINGS, S.C; CALLAWAY, R.M. Salt Marsh Plant Zonation: The Relative Importance of Competition and Physical Factors. Ecology, v.73, p.681-690, 1992. Wiley. Available from: <http:// dx.doi.org/10.2307/1940774>. Accessed: Mar. 09, 2018. doi: $10.2307 / 1940774$.

RIETZ, D.N., HAYNES, R.J. Effects of irrigation-induced salinity and sodicity on soil microbial activity. Soil Biology \& Biochemistry, v.35, p.845-854, 2003. Available from: <file:///C:/ Users/Microsoft\%20Windows/Downloads/Rietz.pdf $>$. Accessed: Mar. 09, 2018. doi: 10.1016/S0038-0717(03)00125-1.

SÁNCHEZ, O. etal. The effect of sodium chloride on the two-stepkinetics of the nitrifying process. Water Environment Research, v.76, p.73-8, 2004. Available from: <https://doi.org/10.2175/106143004X141609>. Accessed: Mar. 11, 2018. doi: 10.2175/106143004X141609.
SANTANA, M.J. et al. Efeitos da salinidade da água de irrigação na brotação e desenvolvimento inicial da cana-de-açúcar (Saccharum spp) e em solos com diferentes níveis texturais. Ciência e Agrotecnologia, Lavras, v.31, p.1470-1476, 2007. Available from: <http://dx.doi.org/10.1590/S1413$70542007000500030>$. Accessed: Nov. 28, 2018. doi: 10.1590/ S1413-70542007000500030.

SILVA, J.T.A. Solo, adubação e nutrição para bananeira. Informe Agropecuário. Cultivo da bananeira. v.36, n.288. p.7483. 2015 .

SILVA, J. T A. et al. Solos, adubação e nutrição da bananeira Informe Agropecuário, Belo Horizonte, v.20, n.196, p.21-36, jan./fev. 1999.

SILVA, J. T A. et al. Produção da bananeira 'Prata anã' (AAB) em função de diferentes doses e fontes de potássio. Rev. Ceres, Viçosa, v.58, p.817-822, Dec. 2011 . Available from: <http:// dx.doi.org/10.1590/S0034-737X2011000600020>. Accessed: Nov. 30, 2017. doi: 10.1590/S0034-737X2011000600020.

SIMONSSON, M. et al. Potassium release and fixation as a function of fertilizer application rate and soil parent material. Geoderma, v.140, p.188-198, 2007. Available from: <https://www.journals. elsevier.com/geoderma> . Accessed: Nov. 15, 2018. doi: 10.1016/j. geoderma.2007.04.002.

SOURI, M.K. Effectiveness of chloride compared to 3,4-dimethylpyrazole phosphate on nitrification inhibition in soil. Communications in Soil Science and Plant Analysis. v.41. p.1769-1778. 2010. Available from: <https://www.researchgate. net/publication/240546502>. Accessed: Nov. 29, 2017. doi: 10.1080/00103624.2010.489139.

SOUZA, M. et al. Banana Prata anã. In: RIBEIRO, A.C.; et al. (Eds.). Recomendações para o uso de corretivos e fertilizantes em Minas Gerais: $5^{\text {a }}$ aproximação. Viçosa: UFV, 1999. Cap.18, p.217-218.

SOUZA, E.D. et al. Frações do carbono orgânico, biomassa e atividade microbiana em um Latossolo Vermelho sob cerrado submetido a diferentes sistemas de manejos e usos do solo. Acta Scientiarum, Maringá, v.28, p.323-329, 2006. Available from: $\quad<$ http://dx.doi.org/10.4025/actasciagron.v28i3.940>. Accessed: Nov. 22, 2018. doi: 10.4025/actasciagron.v28i3.940.

STOTZKY, G. Microbial respiration. In: BLACK, C.A., ed. Methods of soil analysis. Madison, American Society of Agronomy, 1965. p.1551-1572.

VIEIRA-MEGDA, M. X. et al. Contribution of fertilizer nitrogen to the total nitrogen extracted by sugarcane under Brazilian field conditions. Nutrient Cycling in Agroecosystems. v.101, p.241257, 2015. Available from: <https://www.researchgate.net/ publication/272088513>. Accessed: Nov. 30, 2017. doi: 10.1007/ s10705-015-9676-7.

VIEIRA-MEGDA, M.X et al. Chloride ion as nitrification inhibitor and its biocidal potential in soils. Soil Biology and Biochemistry, v.72, p.84-87, 2014. Available from: <https://www.researchgate. net/publication/260215568>. Accessed: May, 19, 2018. doi: 10.1016/j.soilbio.2014.01.030. 